REGARDS

SUR L'ECONOMIE ALLEMANDE

BULLETIN ECONOMIQUE DU CRAC

\section{Regards sur l'économie allemande}

Bulletin économique du CIRAC

$92 \mid 2009$

Varia

\title{
Publicité : migration des budgets vers Internet
}

\section{Isabelle Bourgeois}

\section{OpenEdition}

Journals

Édition électronique

URL : http://journals.openedition.org/rea/3771

DOI : 10.4000/rea.3771

ISBN : 978-2-8218-0880-5

ISSN : 1965-0787

Éditeur

CIRAC

Édition imprimée

Date de publication : 1 juillet 2009

Pagination : 36

ISSN : 1156-8992

Référence électronique

Isabelle Bourgeois, «Publicité : migration des budgets vers Internet », Regards sur l'économie allemande [En ligne], 92 | juillet 2009, mis en ligne le 01 juillet 2011, consulté le 15 septembre 2020. URL : http:// journals.openedition.org/rea/3771

Ce document a été généré automatiquement le 15 septembre 2020

(C) CIRAC 


\title{
Publicité : migration des budgets vers Internet
}

\author{
Isabelle Bourgeois
}

1 Le marché publicitaire allemand a ressenti en 2008 les signes avant-coureurs de la crise : les dépenses totales brutes des annonceurs ont reculé de 2,2\%. Et en 2009, les recettes nettes des supports pourraient diminuer de $5 \%$, voire de $8 \%$ selon les prévisions de la Fédération de branche ZAW. Cette baisse conjoncturelle fait suite à une progression de près de $3 \%$ des recettes nettes enregistrée par les dix principaux supports de 2005 à 2008. Elle inquiète toutefois moins les acteurs de la branche que les mutations structurelles observées dans la destination des budgets: délaissant les supports classiques, en premier lieu la presse écrite, ils migrent massivement vers les supports en ligne. Une évolution parallèle s'observe entre la forte chute de la diffusion des quotidiens (-11\% depuis 2005) et l'explosion du nombre de pages Internet consultées par jour (+ $600 \%)$. (IB)

Evolution des recettes publicitaires nettes des dix principaux supports en RFA 2005-2008

\begin{tabular}{|l|l|l|l|}
\hline & 2005 & 2008 & Evol. \\
\hline & (en millions $€$ ) & (en millions $€$ ) & (en \%) \\
\hline Quotidiens & 4477 & 4373 & $-2,3$ \\
\hline TV & 3930 & 4036 & $+2,7$ \\
\hline Mailing postal & 3398 & 3292 & $-3,1$ \\
\hline Quotidiens d'annonces & 1898 & 2008 & $+5,8$ \\
\hline Presse magazine & 1791 & 1693 & $-5,5$ \\
\hline Annuaires & 1197 & 1225 & $+2,3$ \\
\hline
\end{tabular}




\begin{tabular}{|l|l|l|l|}
\hline Périodiques spécialisés & 902 & 1031 & $+14,3$ \\
\hline Affichage & 769 & 805 & $+4,7$ \\
\hline Internet & 332 & 754 & $+127,1$ \\
\hline Radio & 684 & 711 & $+4,0$ \\
\hline Total & 19378 & 19928 & $+2,8$ \\
\hline
\end{tabular}

Source des données : iwd, n² 27 (02-07-2009) / ZAW.

\section{INDEX}

Mots-clés : publicité, média, Internet, nouvelles technologies, NTIC, marché, conjoncture, presse 